論- 交

\title{
天然ガスによる鉄鉱石の還元について (II)
}

\author{
佐藤良蔵・田畑農夫 \\ REDUCTION OF IRON ORES BY REFORMED NATURAL GAS (II) \\ Ryozo Sato and Nofu Tabata
}

\section{Synopsis:}

In the first paper ("Tetsu-to-Hagane" vol. 41. No. 1. 1955, p. 5 11) the authors reported of the investigations made on reduction process of iron ores by the reformed natural gas. It was found that the decomposition of hydrocarbon in natural gas was one of the most important factors of the reduction process of the ores.

In the present paper are made the studieson the effects of reacting time and of some additions such as salts of alkali and alkaline earth metals on reduction velocity of iron ores by natural gas at low temperature. The results obtained were summarized as follows:

As the reducing action of natural gas was weak, the time for sufficient reduction should be much longer, but when decomposition of hydrocarbon took place, reduction velocity was found to be rapidly increased. The additions of $\mathrm{Na}_{2} \mathrm{CO}_{3}, \mathrm{CaCO}_{3}$, and $\mathrm{CaO}$ were effective to increase the reduction velocity of the ores by natural gas.

Through our experimental results, it was presumed that the decomposition of natural gas was accelerated in consequence of the effects of the additions on reducing power of the gas.

\section{I. 緒 吾}

前報告》にわいて，鉄鉱石の還元剤に天然ガスを使用 した場合，それぞれの反応温度における鉱石別の還元過 程について述へ，天然ガス中の炭化水素の分解と鉄鉱石 の還元との間に相互関係のあることを示した. 即ち，反 応诗の試料状態力湠化水素の分解作用に影響し，乙の分 解反応の開始により還元反応は迅速に進行して還元困難 と見做されている砂鉄さえも充分金属鉄まで還宁され る. 従つて実際作業の立場から考えられる低温で, しか も還元時間の短縮を取上げる時には，との還元反応と分 解反広の相互関係から, 両反店の並行する状態を生み出 すことが望ましいので，ての点に立脚して，更に保持時 間および通常最も入手簡篻な添加郕の還元にわよぼす影 響を知るために行つだ笑験結果の一部を本報告に述べる ことにする.

\section{1. 実 験 要 領}

試料の鉄鉱石および還元放の天然ガスは何れも前報 告)之同しで，ガスの洗源時に今回は $\mathrm{O}_{2}$ のみ除去して 使用した，保持温度は著者の報告2)で示した棣に, $700^{\circ} \mathrm{C}$ 迄と $750^{\circ} \mathrm{C}$ の場合において，ガスの分解過程に明睽な

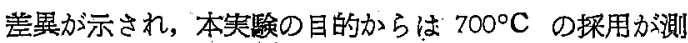
定上好都合なため，同温度を探用した・ガスの送入量は

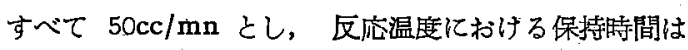
60,90,および $120 \mathrm{mn} の 3$ 段階とした。

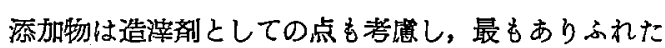
もの, 即ち崖酸壏として $\mathrm{Na}_{2} \mathrm{CO}_{3}, \mathrm{CaCO}_{3}$ また酸化物 として $\mathrm{CaO}$ をえらび，何れも１00mesh 亿撤えたもの を各鉱石によく混合して使用した。添加率は試料鉱石に 対する重量比，反応温度における保持時間は $90 \mathrm{mn} て ゙$ ある.

測定要領㤝発生 $\mathrm{CO}_{2}$ の測定を除去した以外はすべて 前報告のままで,ガス流量の变化，反応終了後の試料分 析によつて反応進行状態を調べた．なお所要温度迄の 加熱時間は略 $60 \mathrm{mn}$ とし，また冷却時のガス送入量を $100 \mathrm{cc} / \mathrm{mn}$ に決めて行つた。

\section{III. 実験結果及び考察}

測定結果は，Table 1〜4，に示す. 本表では，各試料 毎にその㭙間の経過に対する反応の進行状態が示され，

* 昭和 30 年 4 月 6 日，本会撛湍大会にて発表

** 秋田大学鈗山学部 
Table 1. Results observed (Effect of reacting time on reduction of iron ores at $700^{\circ} \mathrm{C}$ )

[T: temperature, $\mathrm{F}_{2}$ : gas-amount flowing out]

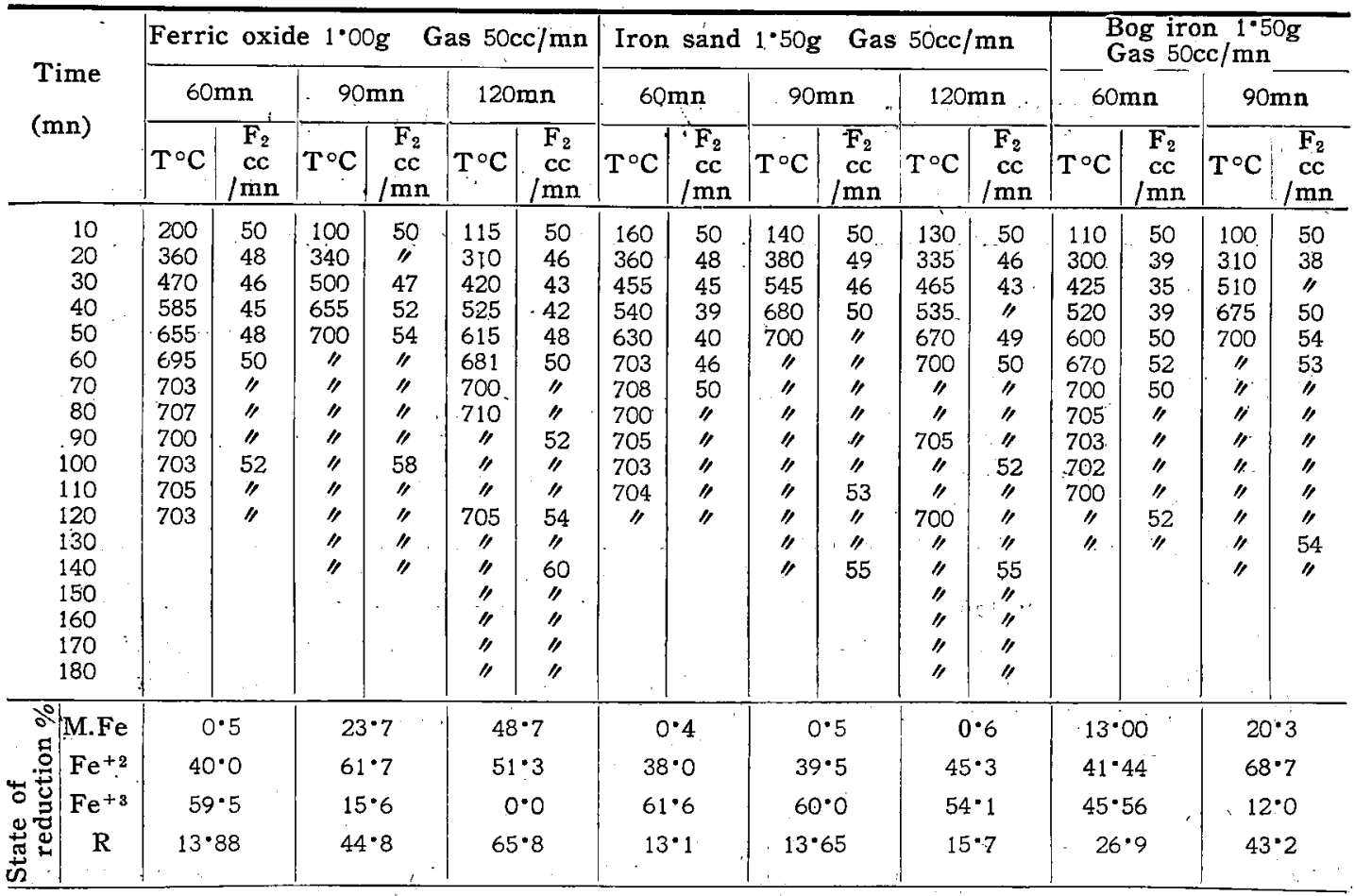

Table 2. Results observed (Reduction of ferric oxide by additions)

[T: temperature $\mathrm{F}_{2}$ : gas-amount flowing out]

\begin{tabular}{|c|c|c|c|c|c|c|c|c|c|c|c|c|c|c|}
\hline \multirow{3}{*}{\multicolumn{2}{|c|}{$\underbrace{\text { Kind }}_{\substack{\text { Time } \\
\text { Ratio } \%}}$}} & \multicolumn{2}{|r|}{ No } & \multicolumn{6}{|c|}{$\mathrm{Na}_{2} \mathrm{CO}_{3}$} & \multicolumn{5}{|c|}{$\mathrm{Ca} \mathrm{CO}_{3}$} \\
\hline & & & \multicolumn{2}{|r|}{4} & \multicolumn{2}{|r|}{6} & \multicolumn{2}{|r|}{10} & \multicolumn{2}{|r|}{4} & \multicolumn{2}{|r|}{6} & \multirow{2}{*}{$T^{\circ} \mathrm{C}$} \\
\hline & & $T^{\circ} \mathrm{C}$ & $\begin{array}{c}\mathrm{F}_{2} \\
\mathrm{cc} / \mathrm{mn}\end{array}$ & $T \cdot C$ & $\begin{array}{c}\mathrm{F}_{2} \\
\mathrm{cc} / \mathrm{mn}\end{array}$ & $T^{\circ} \mathrm{C}$ & $\begin{array}{c}\mathbf{F}_{2} \\
\mathrm{cc} / \mathrm{mn}\end{array}$ & T.C & $\begin{array}{c}\mathrm{F}_{2} \\
\mathrm{cc} / \mathrm{mn}\end{array}$ & $\mathrm{T}^{\circ} \mathrm{C}$ & $\begin{array}{c}\mathrm{F}_{2} \\
\mathrm{cc} / \mathrm{mn}\end{array}$ & $\mathrm{T}^{\circ} \mathrm{C}$ & cc/mn & \\
\hline . & $\begin{array}{r}10 \\
20 \\
30 \\
40 \\
50 \\
60 \\
70 \\
80 \\
90 \\
100 \\
110 \\
120 \\
130 \\
140 \\
150\end{array}$ & $\begin{array}{c}100 \\
340 \\
500 \\
655 \\
700 \\
4 \\
" 1 " \\
" 1 " \\
" 1 \\
" \\
" 1 \\
"\end{array}$ & 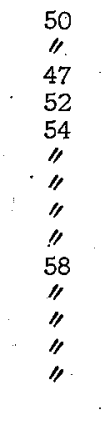 & $\begin{array}{l}130 \\
380 \\
545 \\
655 \\
700 \\
" 1 \\
" 1 \\
" 1 " \\
" 1 " \\
" 1 " \\
" 1 "\end{array}$ & 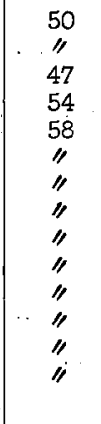 & $\begin{array}{c}130 \\
375 \\
555 \\
680 \\
700 \\
" 1 \\
" 1 \\
" 1 \\
" 1 \\
" 1 \\
" 1\end{array}$ & $\begin{array}{l}50 \\
" 1 \\
47 \\
54 \\
60 \\
58 \\
" 1 \\
" \\
" 1 \\
" 1 \\
" \\
"\end{array}$ & $\begin{array}{c}150 \\
375 \\
555 \\
700 \\
" 1 \\
" \\
" \\
" 1 \\
" 1 " \\
" 1 \\
" \\
"\end{array}$ & $\begin{array}{l}50 \\
1 " \\
47 \\
60 \\
11 \\
58 \\
" 1 \\
" 1 " \\
" 1 " \\
" 1 " \\
"\end{array}$ & $\begin{array}{c}150 \\
365 \\
525 \\
685 \\
700 \\
" 1 " \\
" \\
" 1 \\
" \\
" \\
" 1 \\
"\end{array}$ & 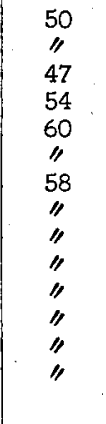 & $\begin{array}{c}100 \\
340 \\
495 \\
655 \\
700 \\
" \\
" 1 " \\
" 1 " \\
" \\
" \\
" 1 \\
" \\
"\end{array}$ & $\begin{array}{l}50 \\
" 1 \\
47 \\
54 \\
58 \\
" 1 \\
" 1 \\
" \\
" 1 \\
" 1 \\
" 1 \\
"\end{array}$ & $\begin{array}{c}130 \\
335 \\
485 \\
595 \\
700 \\
" 1 \\
" \\
" \\
" 1 \\
" \\
" \\
" \\
" \\
"\end{array}$ \\
\hline 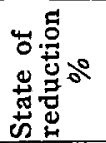 & $\begin{array}{c}\text { M. Fe } \\
\mathrm{Fe}^{+2} \\
\mathrm{Fe}^{+8} \\
\mathrm{R}\end{array}$ & & $\begin{array}{l}23 \cdot 7 \\
61 \cdot 7 \\
15 * 6 \\
44 \cdot 2\end{array}$ & & $\begin{array}{r}40 \cdot 5 \\
59 \cdot 5 \\
0 \cdot 0 \\
60 \cdot 1\end{array}$ & ' & $\begin{array}{c}44 \cdot 2 \\
55 \cdot 8 \\
0 \cdot 0 \\
62 \cdot 8\end{array}$ & & $\begin{array}{r}61 \cdot 1 \\
38 \cdot 9 \\
0 \cdot 0 \\
74 \cdot 0\end{array}$ & 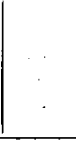 & $\begin{array}{r}31.4 \\
60.0 \\
8.6 \\
51.4\end{array}$ & . & $\begin{array}{r}36 \cdot 0 \\
64 \cdot 0 \\
0 \cdot 0 \\
57 \cdot 3\end{array}$ & \\
\hline
\end{tabular}


各鉱石共時問の経過によつて前報告に述べた様な過程を 示している. 只その反応の進行状態は試料の状態によ うて变化し，特に添加物の影響がよく示されている。

A. 反応時間の影響

反応温度が $700^{\circ} \mathrm{C}$ であるため，各鉱石共反応の准行 が緩慢で，特に砂鉄では，90mn, $120 \mathrm{mn}$ の保持でもガ スの分解は極めて槿少量しか諗められない。またその還 元率の変化も少なく，艺の内容は殆んどが $\mathrm{Fe}^{+3} \rightarrow \mathrm{Fe}^{+2}$ で占めている.

然し，酸化第二鉄および沼鉄鉱では 60mn 保持でも 分解の開始力認められ，乙れか洔間の経過従つて次第 に進行し，還元率の上昇も漸次増大の傾向を汕るてとが 示されている．即ち，一広被還元性の大きい鉱石程，乙 の保持時間の延長の効果がよく現われることになりそ の還元進行の程度は時間と䢬元率汃ら求好得る。乙れ等 を通して天然ガス自体の組成では，700ㄷ 亿おける分解 反応速度は㯼めて小さく，その還元力の弱さから被還元 﨡に大きく左右されるものと考えられる。従つて，被還 元性の大きい酸化第二鉄や沼鉄鉱では時間経過の影響が 砂鉄に比較して割に大きく，またその進行傾向の増大の 点から還元と分解の進行との相互関係がくく現われると むいえよう・沼鉄鈸の場合比見られる反応進行傾问のた るみは沼鉄鉱のるつ結合水分および有機物等の影響であ ろうことも筧える。

\section{B. 添加物の影響}

次に滰加物の効果を見るため，上記諸原加物を 0〜10

\begin{tabular}{|c|c|c|c|c|c|c|}
\hline \multirow{3}{*}{ 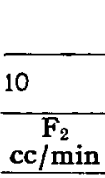 } & \multicolumn{6}{|c|}{$\mathrm{CaO}$} \\
\hline & \multicolumn{2}{|r|}{4} & \multicolumn{2}{|r|}{6} & \multicolumn{2}{|r|}{10} \\
\hline & $\mathrm{T}^{\circ} \mathrm{C}$ & $\begin{array}{c}F_{2} \\
\mathrm{cc} / \mathrm{min} \\
\end{array}$ & $\mathrm{T}^{\circ} \mathrm{C}$ & $\begin{array}{c}F_{2} \\
\mathrm{cc} / \mathrm{min}\end{array}$ & $\mathrm{T}^{\circ} \mathrm{C}$ & $\begin{array}{c}\mathrm{F}_{2} \\
\mathrm{cc} / \mathrm{min}\end{array}$ \\
\hline $\begin{array}{l}50 \\
4 \\
47 \\
50 \\
52 \\
58 \\
" 1 \\
" 1 \\
" 1 \\
" 1 \\
" 1 \\
" 1 \\
" 1\end{array}$ & $\begin{array}{c}155 \\
360 \\
530 \\
680 \\
700 \\
" \\
" 1 \\
\text { " } \\
\text { " } \\
\text { " } \\
\text { " }\end{array}$ & $\begin{array}{l}50 \\
47 \\
47 \\
54 \\
60 \\
58 \\
" 1 \\
" 1 \\
" 1 " \\
" 1 " \\
" 1 " \\
" 1\end{array}$ & $\begin{array}{c}140 \\
355 \\
535 \\
655 \\
700 \\
" 1 \\
" 1 \\
" 1 \\
" 1 " \\
" 1 " \\
" 1 \\
" 1\end{array}$ & $\begin{array}{l}50 \\
" 1 \\
47 \\
60 \\
58 \\
" 1 \\
" 1 \\
" 1 " \\
" 1 " \\
" 1 " \\
" 1 \\
" 1\end{array}$ & $\begin{array}{c}230 \\
420 \\
595 \\
705 \\
" 1 \\
700 \\
" \prime \\
" 1 \\
" 1 \\
" 1 \\
" 1 \\
" 1\end{array}$ & $\begin{array}{l}50 \\
" 1 \\
51 \\
60 \\
58 \\
" 1 \\
" 1 \\
" 1 \\
" 1 \\
" 1 \\
" 1 \\
" 1\end{array}$ \\
\hline $\begin{array}{r}33.0 \\
66.0 \\
0.0 \\
55 \cdot 0\end{array}$ & & $\begin{array}{r}30 \cdot 3 \\
69 \cdot 7 \\
0 \cdot 9 \\
53 \cdot 5\end{array}$ & & $\begin{array}{r}33 \cdot 0 \\
67 \cdot 0 \\
0 \cdot 0 \\
55^{\circ} 4\end{array}$ & & $\begin{array}{l}37 \cdot 8 \\
2 \cdot 2 \\
0 \cdot 0 \\
8 \cdot 5\end{array}$ \\
\hline
\end{tabular}

\%の範囲で使用した結果，何れも還元率が上昇し，反応 促進上有効であるととが示された。またた添加率の影響は 率の增加と共に大きく，添加物の種別による効果上の羑 異はあつたが，大体 6〜10\%の添加率で充分な效果をあ げている.

まず，酸化第二鉄については Fig・1〜3 亿示す結果 を得た。即ち $\mathrm{Na}_{2} \mathrm{CO}_{3}$ を添加すると，源加卒が大にな るにつれてガスの分解開始が早くなり，還元率は10\%涯 加で $74 \%$ に達する. $\mathrm{CaCO}_{3}$ および $\mathrm{CaO}$ もをの傾问 は $\mathrm{Na}_{2} \mathrm{CO}_{3}$ と略々同じであるが還元率では約 10\%位低 下した值を示す。一方雾囲気の状態は何れの場合も流入 流出ガスの容量变化において $1 ・ 16$ 倍で，涯加率による

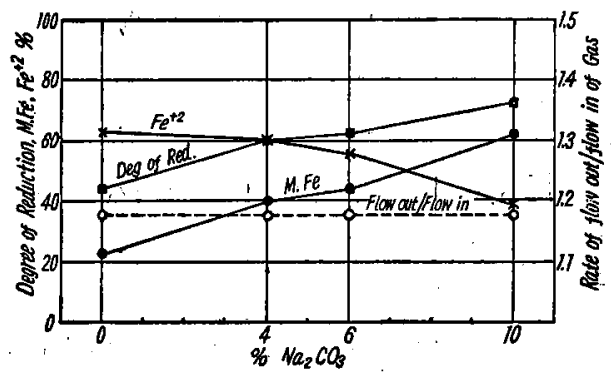

Fig. 1. Effect of $\mathrm{Na}_{2} \mathrm{CO}_{3}$ content on reduction of ferric oxide and change of gas amount.

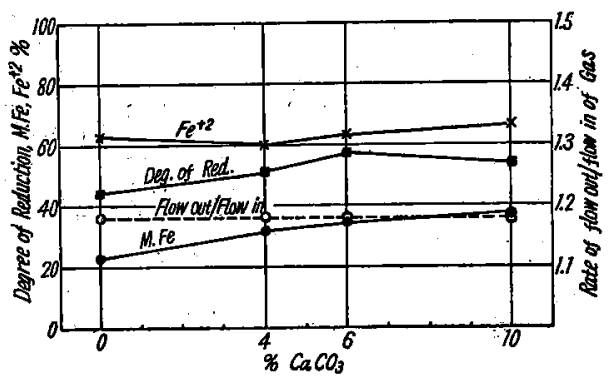

Fig. 2. Effect of $\mathrm{CaCO}_{3}$ content on reduction of ferric oxide and change of gas anount.

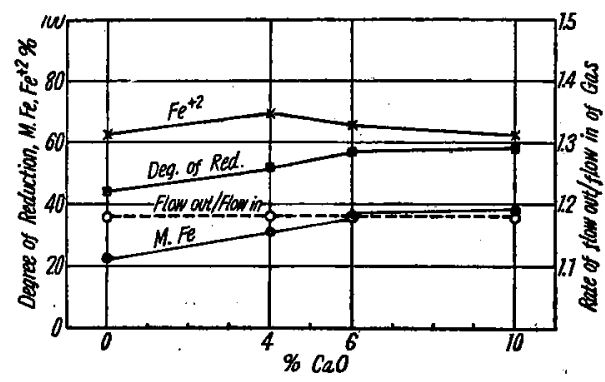

Fig. 3. Effect of $\mathrm{CaO}$ content on reduction of ferric oxide and change of gas amount. 


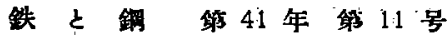

Table 3. Results observed (Reduction of iron sand by additions)

[T:temperature $F_{2}$ : gas-amount flowing out]

\begin{tabular}{|c|c|c|c|c|c|c|c|c|c|c|c|c|c|c|}
\hline 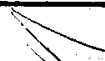 & Kind & & No : & & & $\mathrm{Na}_{2}$ & $\mathrm{CO}_{3}$ & · & & & & $\mathrm{Ca}$ & $\mathrm{CO}_{3}$ & \\
\hline 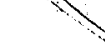 & Ratio \% & & 0 & & 4 & & 6 & & 10 & & 4 & & 6 & \\
\hline $\begin{array}{l}\text { Time } \\
\text { (mn) }\end{array}$ & & $\mathrm{T}^{\circ} \mathrm{C}$ & $\begin{array}{c}F_{2} \\
\mathrm{cc} / \mathrm{mn}\end{array}$ & $\mathrm{T}^{\circ} \mathrm{C}$ & $\begin{array}{c}\mathrm{F}_{2} \\
\mathrm{cc} / \mathrm{mn}\end{array}$ & $\mathrm{T}^{\circ} \mathrm{C}$ & $\begin{array}{c}\mathrm{F}_{2} \\
\mathrm{cc} / \mathrm{mn}\end{array}$ & $\mathrm{T}^{\circ} \mathrm{C}$ & $\begin{array}{c}\mathrm{F}_{2} \\
\mathrm{cc} / \mathrm{mn}\end{array}$ & $T^{\circ} \mathrm{C}$ & $\begin{array}{c}\mathrm{F}_{2} \\
\mathrm{cc} / \mathrm{mn}\end{array}$ & $\mathrm{T}^{\circ} \mathrm{C}$ & $\begin{array}{c}F_{2} \\
\mathrm{cc} / \mathrm{mn}\end{array}$ & $\mathrm{T}^{\circ} \mathrm{C}$ \\
\hline & $\begin{array}{c}10 \\
20 \\
30 \\
40 \\
50 \\
60 \\
70 \\
80 \\
90 \\
100 \\
110 \\
120 \\
130 \\
140 \\
150\end{array}$ & $\begin{array}{c}140 \\
380 \\
545 \\
680 \\
700 \\
" 1 \\
" 1 \\
" 1 \\
" \\
" 1 " \\
" 1 \\
" 1\end{array}$ & $\begin{array}{l}50 \\
49 \\
46 \\
50 \\
" 1 \\
" 1 \\
" 1 \\
" 1 \\
" 1 \\
53 \\
" 1 \\
55\end{array}$ & $\begin{array}{c}140 \\
380 \\
545 \\
680 \\
700 \\
" 1 \\
" \\
" \\
" \\
" \\
" \\
" \\
" \\
"\end{array}$ & $\begin{array}{l}50 \\
" 1 \\
47 \\
50 \\
" 1 \\
53 \\
" 1 \\
54 \\
" 1 \\
" 1 \\
" 1 \\
53 \\
" 1\end{array}$ & $\begin{array}{c}160 \\
415 \\
555 \\
680 \\
700 \\
" 1 \\
" 1 \\
" \\
" \\
" 1 \\
" \\
" \\
" 1\end{array}$ & $\begin{array}{l}50 \\
47 \\
45 \\
51 \\
52 \\
53 \\
" 1 \\
\text { " } \\
54 \\
" 1 \\
" 1 \\
" 1 \\
" 1 \\
" 1\end{array}$ & $\begin{array}{c}140 \\
365 \\
535 \\
655 \\
700 \\
" 1 \\
\text { " } \\
\text { " } \\
\text { " } \\
\text { " " " }\end{array}$ & $\begin{array}{l}50 \\
47 \\
45 \\
51 \\
53 \\
" 1 \\
" 1 \\
58 \\
" 1 \\
" 1 \\
" 1 \\
" 1 \\
60\end{array}$ & $\begin{array}{l}170 \\
385 \\
555 \\
700 \\
\prime \prime \\
\prime \prime \\
\prime \prime \\
" \\
" 1 " \\
" \\
"\end{array}$ & $\begin{array}{c}50 \\
" 1 \\
45 \\
52 \\
" 1 \\
55 \\
1 " \\
57 \\
60 \\
67 \\
74 \\
75 \\
" \\
\vdots \\
\vdots\end{array}$ & $\begin{array}{c}140 \\
390 \\
525 \\
670 \\
700 \\
" 1 \\
" \\
" 1 \\
" 1 \\
" . \\
" 1 \\
" 1 \\
"\end{array}$ & $\begin{array}{l}50 \\
" 1 \\
47 \\
53 \\
56 \\
" 1 \\
57 \\
72 \\
77 \\
" 7 \\
75 \\
" \\
"\end{array}$ & $\begin{array}{c}160 \\
385 \\
575 \\
700 \\
" \prime \\
" 1 \\
" 1 \\
" 1 \\
" 1 \\
" 1 \\
" 1\end{array}$ \\
\hline 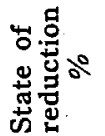 & $\begin{array}{c}\mathrm{M} . \mathrm{Fe} \\
\mathrm{Fe}^{+2} \\
\mathrm{Fe}^{+3} \\
\quad \mathrm{R}\end{array}$ & & $\begin{array}{l}0.5 \\
39 \cdot 5 \\
60 \cdot 0 \\
13 \cdot 65\end{array}$ & & $\begin{array}{r}2 \cdot 4 \\
32 \cdot 7 \\
65 \cdot 9 \\
13 \cdot 3\end{array}$ & & $\begin{array}{l}6 \cdot 75 \\
52 \cdot 05 \\
41 \cdot 20 \\
24 \cdot 5\end{array}$ & & $\begin{array}{l}15 \cdot 2 \\
61 \cdot 0 \\
23 \cdot 8 \\
35 \cdot 5\end{array}$ & . & $\begin{array}{r}46 \cdot 5 \\
53 \cdot 5 \\
0 \cdot 0 \\
64 \cdot 2\end{array}$ & & $\begin{array}{r}72 \cdot 0 \\
28 \cdot 0 \\
0 \cdot 0 \\
81 \cdot 3\end{array}$ & \\
\hline
\end{tabular}

Table 4. Results observed (Reduction of bog iron by additions).:

[T: temperature $F_{2}$ : gas-amount flowing out]

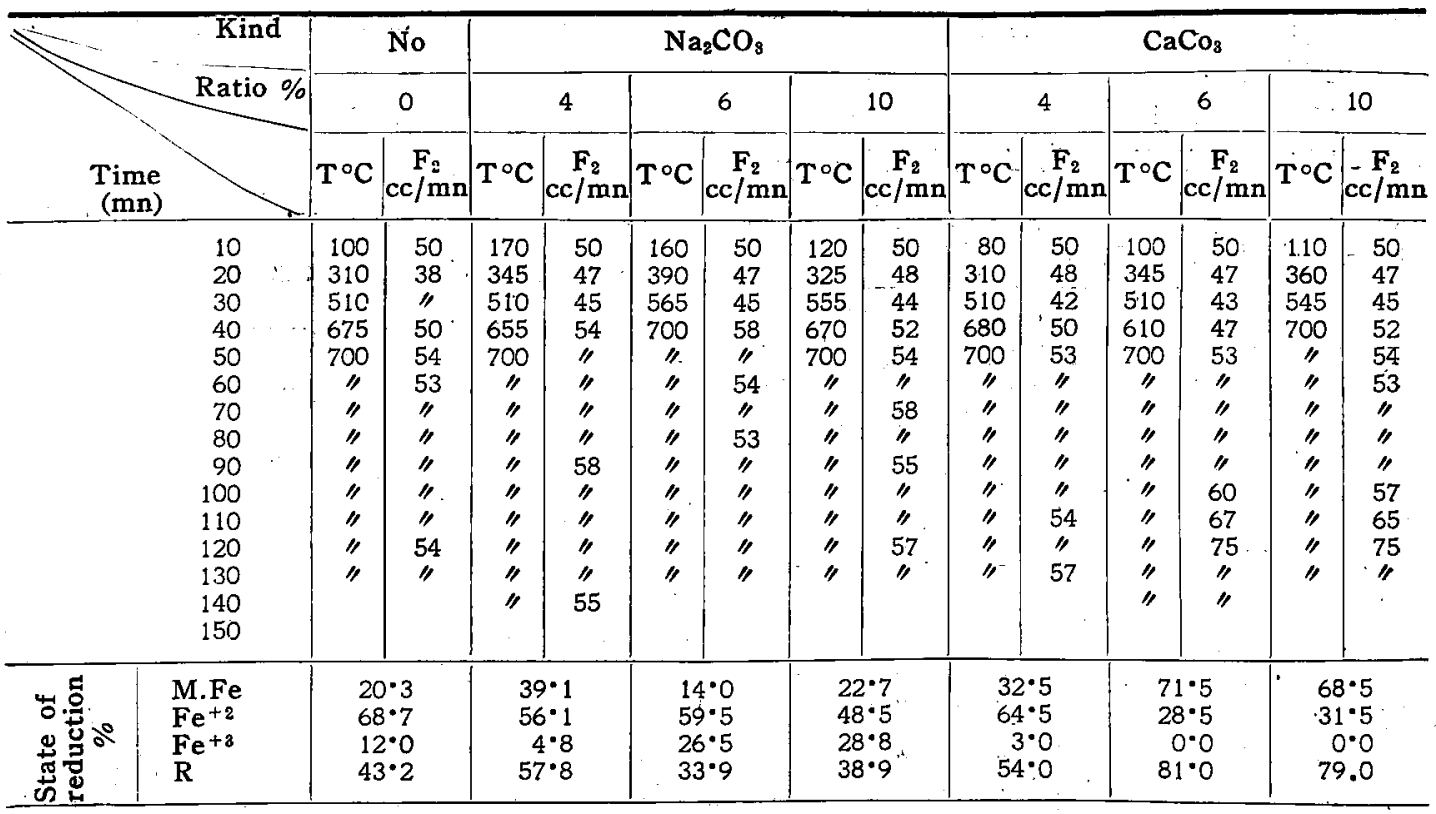

变化はでく僅かである。これを反広時間の影響に比較す れば，その反応の進行状態の点では大差が鵃い様にお゙ われ，比較的保持時間の経過に対する反応の進行により， むしろ所要温度に達する間に行われる反店に源加物の效

\section{果が認められる。}

次に砂鉄についてみると，Fig. 4〜6 亿示す如く，添 加物の效果を最をるく示している. 即ち, $\mathrm{CaCO}_{3}, \mathrm{CaO}$ の場合は何れも時間の経過が 60mn 上後になると，ガ 


\begin{tabular}{|c|c|c|c|c|c|c|}
\hline \multirow[b]{2}{*}{10} & \multicolumn{6}{|c|}{$\mathrm{CaO}$} \\
\hline & \multicolumn{2}{|r|}{4} & \multicolumn{2}{|c|}{. 6} & \multicolumn{2}{|r|}{10} \\
\hline $\begin{array}{c}\mathrm{F}_{2} \\
\mathrm{cc} / \mathrm{mn}\end{array}$ & $\mathrm{T}^{\circ} \mathrm{C}$ & $\begin{array}{c}\mathrm{F}_{2} \\
\mathrm{cc} / \mathrm{mn}\end{array}$ & $\mathbf{T}^{\circ} \mathrm{C}$ & $\begin{array}{c}\bar{F}_{2} \\
\mathrm{cc} / \mathrm{mn}\end{array}$ & $\mathrm{T}^{\circ} \mathrm{C}$ & $\begin{array}{c}\mathrm{F}_{2} \\
\mathrm{cc} / \mathrm{mn}\end{array}$ \\
\hline $\begin{array}{l}50 \\
" 1 \\
47 \\
53 \\
56 \\
57 \\
" 1 \\
60 \\
68 \\
77 \\
75 \\
11 \\
11\end{array}$ & $\begin{array}{c}130 \\
365 \\
505 \\
650 \\
700 \\
" 1 \\
" 1 \\
" 1 \\
" \\
" 1 \\
" \\
"\end{array}$ & $\begin{array}{l}50 \\
" 1 \\
47 \\
55 \\
57 \\
" 1 \\
" 1 \\
63 \\
73 \\
74 \\
75 \\
" 1 \\
" 1\end{array}$ & $\begin{array}{c}120 \\
355 \\
535 \\
680 \\
700 \\
" \\
" 1 \\
" 1 \\
" \\
" 1 \\
" \\
" 1\end{array}$ & $\begin{array}{c}50 \\
" 1 \\
47 \\
54 \\
" 1 \\
58 \\
" 1 \\
63 \\
75 \\
" 1 \\
" 1 \\
" 1\end{array}$ & $\begin{array}{c}140 \\
330 \\
515 \\
640 \\
700 \\
" 1 \\
" \\
" 1 \\
" \\
" \\
" \\
" \\
" \\
"\end{array}$ & $\begin{array}{l}50 \\
4 \\
47 \\
53 \\
60 \\
63 \\
\text { "1 } \\
65 \\
75 \\
\text { " } \\
\text { "' } \\
\text { "' } \\
\text { " }\end{array}$ \\
\hline $\begin{array}{r}70^{\circ} 5 \\
29 \cdot 5 \\
0 \cdot 0 \\
80^{\circ} 3\end{array}$ & & $\begin{array}{r}63^{\circ} 0 \\
37^{\circ} 0 \\
0.0 \\
75^{\circ} 3\end{array}$ & & $\begin{array}{r}65 \cdot 2 \\
34 \cdot 8 \\
0 \cdot 0 \\
76 \cdot 8\end{array}$ & & $\begin{array}{r}66 \cdot 0 \\
34 \cdot 0 \\
0 \cdot 0 \\
77 \cdot 3\end{array}$ \\
\hline
\end{tabular}

スの容量变化が大きく現われ，てれ等の試料の還元率は

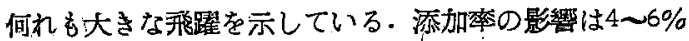
の範囲で効果は著しく示され，10\%迄でそれ以上の源加 亿対する効果は期待できなかつた。還元率は何れも6 10\% 添加で 80\% 前後に達し,ガス容量の変化率は 1.5 倍汇達している。また分解開始の時期もこの両者は殆ん ぞ差がなかつた。

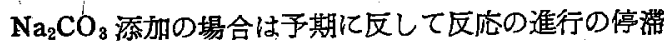
放現われ，6〜10\% 添加において漸く反応の進行が予期 に近いるのに变つて示された・てれは沼鉄鉱の場合にも 認められ，かかる停滞を認めた武料仙は焼着状態力確認 され，試料によつて表面のみの還元や焼着物か現われた ものもあつた。

かかる砂鉄における還元の著しい進行は前報告におい

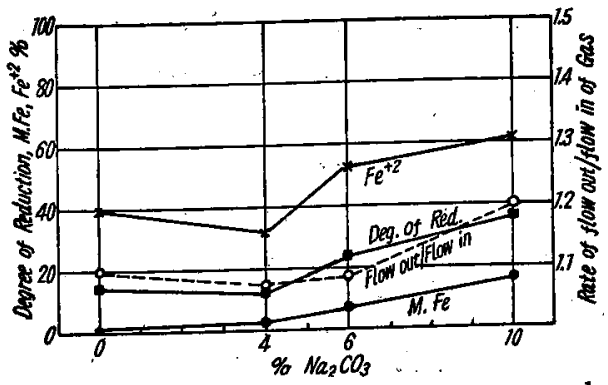

Fig. 4. Effect of $\mathrm{Na}_{2} \mathrm{CO}_{3}$ content on reduction of iron sand and change of gas amount.

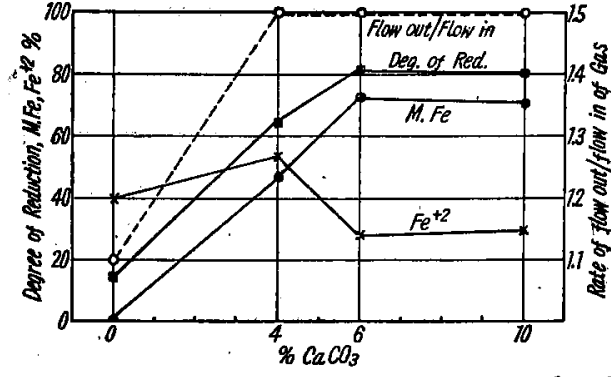

Fig. 5. Effect of $\mathrm{CaCO}_{3}$ content on reduction of iron sand and change of gas amount.

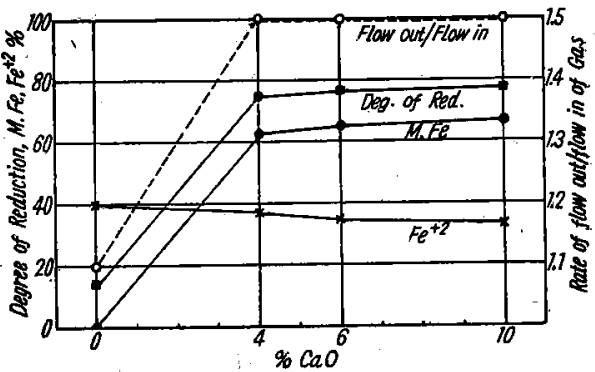

Fig. 6. Effect of $\mathrm{CaO}$ content on reduction of iron sand and change of gas amount.

ても $800^{\circ} \mathrm{C}$ の場合の様に宸化水素の分解進行の項で認 められたが，ての著しい還元速度の堌加は更にかかる添 加物の作用によつても得られるてとか諰められ，分解反 応は単に温度のみならず，還元過程における還元生成物 の影響も大きいてとが明らかになつた．従つて涯加物の 選択は反応系を構成する鉄鉝石の状顛をガスの分解反応 促進の役㓶を果せるものにするためにも考慮されるべき であろう・

沼鉄銶の場合は Fig. 7て8 亿示す様な結果を示し， $\mathrm{Na}_{2} \mathrm{CO}_{3}$ 添加では 6 10\% と添加萃が増加するにつ机 て, 反応の停滞が眀瞭になり, ガスの变化量も却つて小 さく，分解反応の停滞も示されている．而してての場合

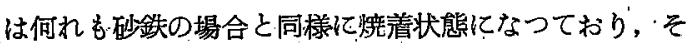
の程度は砂鉄よりを甚だしい。

然し, $\mathrm{CaCOO}_{3}$ 源加の場合にはその効果力眀瞭に示さ れ，還元の進行は涯加荃に店して堌大し，6〜10\% でそ の効果は一定になる：また分解反応の点では，砂鉄の場 合に比較して, その進行にやや多くの時間を要し，最終 容量变化率は全く砂鉄の場合と同じ.1・5 倍になつてい る.還元率は略々砂鉄のそれと同率を示した。

最後江鉙石別による源加物の還元状態に与える影響を 比較するために $\mathrm{Na}_{2} \mathrm{CO}_{3}$ と $\mathrm{CaCO}_{3}$ とついて Fig. 9 〜10 示した。 


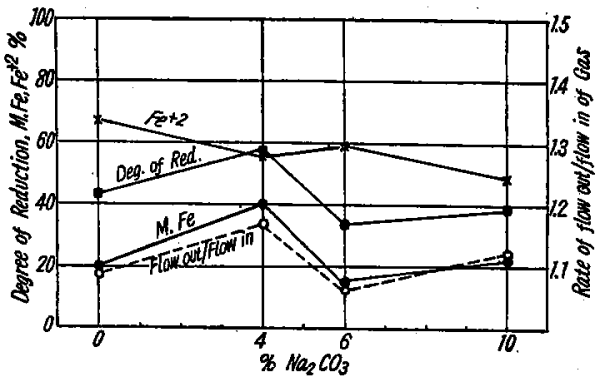

Fig, 7. Effect of $\mathrm{Na}_{2} \mathrm{CO}_{3}$ content on reduction of bog iron and change of gas amount.

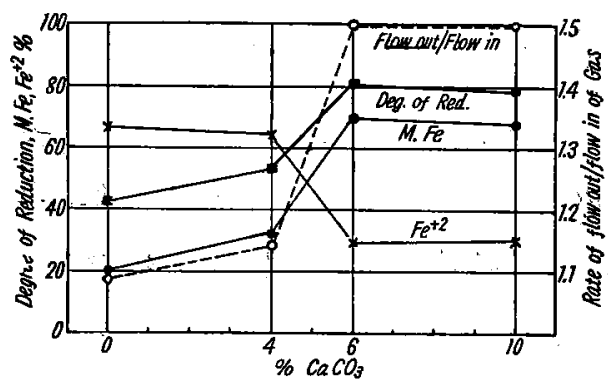

Fig. 8. Effect of $\mathrm{CaCO}_{3}$ content on reduction of bog iron and change of gas amount.

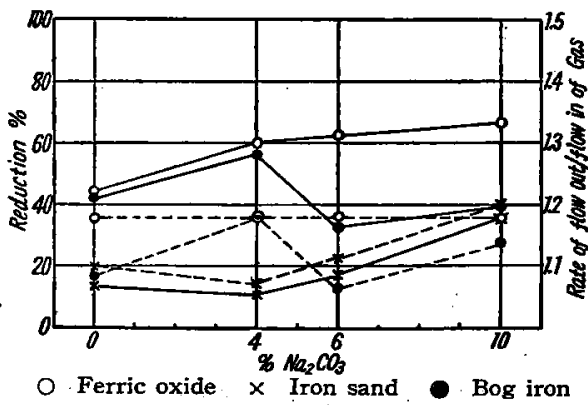

Reduction $\%$.... Flow out/Flow in

Fig. 9. The relation between reduction $\%$ and change of gas amount by addition of $\mathrm{Na}_{2} \mathrm{CO}_{3}$.

即ち， $\mathrm{Na}_{2} \mathrm{CO}_{3}$ の場合，酸化第二鉄にあつては還元反 応の進行に有効な結果を示しているが，時間経過の掦合 に比較すれば，美程明瞭な相異を示さない。ガス容量变 化も添加窈による变化はなく，すべて $1 \cdot 16$ 倍で一定し ている. 砂鉄, 沼鉄鉣では区応の促進に役立つ傾向を示 すが，随伴鉱物の在存か焼着現象を萑起し，このため還 元反応が停滞する．また分解反応もその傾向が同し様に

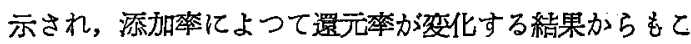
の焼着状態か㯰元に著しい妨害となつていることがわか る.

$\mathrm{CaCO}_{3}$ の添加の場合は, その還元に対する効果か極

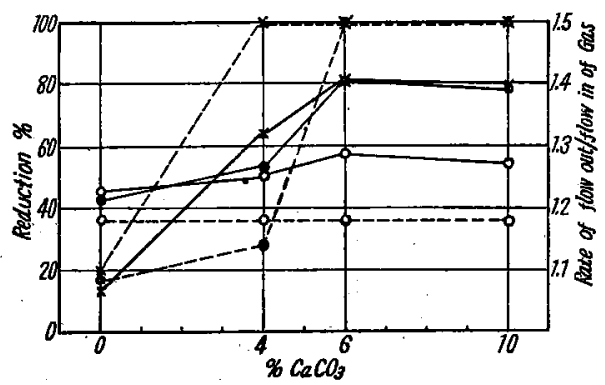

$O$ Ferric oxide $x$ Iron sand - Bog iron

- Reduction $\%$.... Flow out/Flow in

Fig. 10. The relation between reduction $\%$ and change of gas amount by addition of $\mathrm{CaCO}_{3}$.

めて明膫で, 6 〜 10\% 添加で砂鉄，沼鉄鉱は何れも80\% 近くの還元率を得ている.またてれ等ではガス容量変化 も明瞭で約 1.5 倍の值を示し,分解反店の進行々還元反 応の進行とが全く相互関係にあり, 两反応の並行か還元 の進行上決定的条件となつているととが示されている.

具上の笑験結果からすると，天然ガスの様に炭化水菜 を主成分にするむのの還元作用はそれ自体では弱いため 難睘元性の鉱石に対しては殆んば実用的還元成として取 上げるととが困難視されるが，との炭化水素の分解が行: われると，その生成ガスは極めて強力な還元力を有する ため，還元性を規定する搘因子に制約される点が極めて 少くなり，何れの鉣石にあっても纽速に還元力淮行する。 而してこの分解反応に対して還元過程にある鉄酸化物の 状態が主要因子と見做されるため，ととで取上げた源加 風が天然ガスに対してその還元反応に効果をもたらした 事実は，乙れ等の添加物が天然ガスの分解区応に效果を もたらしたというよりも，その反応過程からして天然が ス自体の還元作用に対して有效であつたために，その結 果としてガスの分解を促進する鉄酸化物の状態を持ち来 した結果と考えられる。

勿論これ等の添加物が应機構上如何に働くかを，本 実験範囲で求めるととは無謀なことであり，かつ組成の 複雑さがその困難なことを示しているだけに予想すら容 易なととでは無い。

何れにしろ，てれ等の涯加物は造唕成の一種でもある ため後の処理に刘しても有利なため，低温でかつ迅速還 元を望む立場からは温度，ガス送入量等と同様，極めて 有効であるといい得る。

\section{IV. 総 括}

本報告では天然ガスと鉄鉱石との組合せによる還元反 
応に関し，反応時間および添加物の效果についての美験 を行つた結果を述べたが，それ等を要約すると次の如く である.

1. 低温において，還元反応は時間の経過につれて進 行ずるが，鉱石が難還元性のものではガス自体の還元力 の弱さのため殆んど進行しない，しかし，還元容易な鉱 石ではその容易さが大なるもの程反応が進み，その進行 によつてガスの分解反応が意起され，還元は飛躍的に進 行する。

2. $\mathrm{Na}_{2} \mathrm{CO}_{3}, \mathrm{CaCO}_{3}, \mathrm{CaO}$ を鉱石飞深加すると, 還元反応は何れも進み，還元容易な鉱石にあつては反応 時間の影響で見られる絓果と略々同じ進行状態を示す. 難還元性の鉱石では，還元の進行とガス分解との相互関 係が眀瞕に示され，添加の效果が極めて著しく，温度，
ガス送大量等と同様還元促進に有効なととがわかつた。

3. 添加赤の量的留係は量の堌加に応じて還元は進む が，6〜10\% でその效力は充分で，それ上上の添加は特 別の効果の问上を示さない，只鉉石の種別によつては添 加物との間に焼艮現象を呈するものがあり，かかる場合 は反度の進行が著しく阻害される.

4.反応経過からすれば，反庆系内の鉃酸化物の状態 がガスの分解反応に対し，主要因子の一つで，涯加物は との鉄酸化物の状態生成に重要な役割を果するのと考え られる: (昭和 30 年 5 月寄稿)

\section{文 浻}

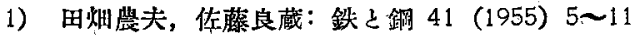

2）佐藤良蔵，田烟農夫: 秋田大学地下資源開発研究 所報告 No. 11 (1954) 49 -55

\section{製鉄用硫酸滓の基礎的研究 (I $)^{*}$}

\section{秋 本 寅 一***大西 信三郎*** \\ FUNDAMENTAL RESEARCH OF PYRITE CINDERS \\ AS PIG MAKING MATERIAL (I) \\ Toraichi Akimoto and Sinzaburo Onishi}

Spnosis:

To clarify the differences in the reducing behavoirs according to the composition of pyrite cinders, the cinders were investigated as follows:

(1) Reduction efficiency on the reaction of $\mathrm{CO}$ gas and pitch coke.

(2) Measurement of the permeability (A. F. A) at various high temperatures.

(3) Compared with the surface conditions of cinder grains by electron microscopic examination.

(4) Measurement of the surface area by Bet process:

\section{I. 緒 带}

食料増㡲に久くべからざるものは硫安肥料であるから との原料として，必要なる硫酸を確保するととは緊急な ととである.

さて硫酸を作るには硫化鉄鉱か入用である．硫化鉄鉱 より $\mathrm{SO}_{2}$ ガスをとつた殘渣即ち硫酸浑は $\mathrm{Fe}$ 多く, 残 留 S比較的少なきために製銑原料として使用するてとは 資源の少ない我国には大切なことである。

使用した硫酸㳯は Table 1 に宗す如く細粒に微粒子 の加つた厄介粉鉱である.

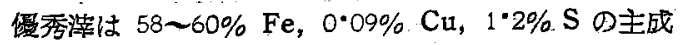

Table 1. Sieving test of cinders.

\begin{tabular}{l|l|l|l|l|l|l}
\hline Mesh & +48 & +65 & +100 & +150 & +200 & -200 \\
\hline$\%$ & $1 \cdot 8$ & $3 \cdot 5$ & $13 \cdot 2$ & $21 \cdot 0$ & $8: 8$ & $51 \cdot 7$ \\
\hline
\end{tabular}

分のものであるから，電気坚で軗銑するか或いは焼結炉 で焼結鉱としている.

現在の愹鉱师では焼結鉱を $20 \sim 60 \%$ 1) 加兑て操業を

* 昭和 30 年 4 月本会軴演大会にて発表

** 日本電式㳖鉄会社

***，要媛大学工学部治金教室 